811.163.41'367.52"17/18"

811.163.41'367

https://doi.org/10.18485/sj.2019.24.1.27

ТОМИСЛАВ М. МАТИЪ ${ }^{*}$

Универзитет у Београду

Филолошки факултет
Оригинални научни рад

Примљен: 27. 11. 2018.

Прихваћен: 15. 01. 2019.

\title{
ТЕОРИЈСКИ ПРИСТУП РЕДУ РЕЧИ У ГРАМАТИКАМА СРПСКОГ ЈЕЗИКА И ЈЕЗИЧКИМ СТУДИЈАМА С КРАЈА XVIII И ИЗ ПРВЕ ПОЛОВИНЕ ХІХ ВЕКА
}

У раду ће бити представљен, анализиран и теоријски размотрен ред речи као специфичан синтаксички репрезент језика епохе у граматикама и језичким студијама из XVIII и XIX века.

Намера нам је да установимо да ли ставови граматичара тога времена следе синтаксичке карактеристике славеносрпског периода, а с друге стране и да ли се у њима могу препознати синтаксичке особености народног (говореног) језика тога времена, кроз њега индиректно и савременог српског језика.

Кључне речи: ред речи, синтакса, (реченица, синтагма, атрибут, глагол) црквенословенски језик, славеносрпски језик, српски језик.

Овај рад представља наставак истраживања о реду речу у славеносрпској епохи, а уз рад објављен у претходном годишту Срйског језика (Матић 2018) представља део ширег научног интересовања аутора које ће бити представљено и заокружено у будућој докторској дисертацији, са темом Функиије реда речи у делу Јоакима Вујића ${ }^{1}$.

Србска синйакса Ђуре Даничића из 1858, Извод из срӣске грамайике, (књига друга, IV део грамайике.) Синйакса Јована Бошковића из 1864,

*t.matic@yahoo.com

${ }^{1}$ Тема је прихваћена на седници наставно-научног већа Филолошког факултета у Београду јануара 2017. године. 
Срйска синйакса Стојана Новаковића из $1870^{2}$, те Срйска синӣакса Јована Живановића из 1889. године представљају најстарије монографске студије које се баве искључиво синтаксом српскога језика. Велики утицај на српске синтаксичаре имала је и Grammatica della lingua serbo-croata Петра Будмана из 1867. године. Доживела је бројне преводе $(1887,1892,1897,1901)$, а заједничко за све њих је да представљају извод из граматике и да носе наслов Срйска синйакса, те стога заслужује да буде посматрана равноправно са претходно наведеним студијама ${ }^{3}$. Нажалост, за све њих се може констатовати да реду речи као специфичном снтаксичком репрезенту епохе није посвећена, чини нам се, адекватна пажња. Посебну тежину томе даје чињеница да је у време настајања тих студија продукцција књига писаних славеносрпским језиком (или било којим другим славизираним дискурсом) и даље велика, те да стога специфични ред речи у реченици представља изузетну демаркациону категорију. У претходном раду истакли смо:

Тек ће Пера Ђорђевић у својој приступној беседи академији наука „О реду речи у српском језику” из 1898. године описати стање у српској вуковској реченици XIX века, на корпусу народне књижевности. Свакако најпрепознатљивија студија о реду речи у савременом српском језику је докторска дисертација Љубомира Поповића „Ред речи у савременом српскохрватском језику” из 1972. године, прерађена и објаљена (у два издања, 1997. и 2004. године) под насловом „Ред речи у реченици” (Матић 2018: 488).

И Стојан Новаковић у посланици Српској краљевској академији наглашава да нам тиреба много рада када су у питању стилистичке и синтаксичке студије српског језика, а да, између осталог, синйакса о реду речи и реченииа није ни зайочейа да се обрађује (Новаковић 1888: 35-36).

Вођени овим закључцима, одлучили смо да у овом раду истражимо и прикажемо синтаксичка разматрања у српским граматикама и језичким студијама из ранијег периода, краја XVIII и прве половине XIX века. Прецизније, настојаћемо да испитамо какви су, евентуални, ставови граматичара тога периода о реду речи као синтаксичкој категорији, те да ли они и у којој мери ред речи схватају као синтаксичку изузетност одређеног језичког регистра свога времена. Покушаћемо да утврдимо и дефинишемо разлике у приступу синтаксичким проблемима у њима, да утврдимо да ли и у којој мери оне зависе од типа образовања аутора, од филолошке средине у којој стварају, као

${ }^{2}$ Прве Новаковићеве (монографске) студије из српске синтаксе везују се за претходну, 1869. годину, када су, прва у форми рукописа, објављене две кратке (16 и 46 страна) студије под сличним именом, Срйска синӣакса у изводу. Будући да су мањег обима и да, како и аутор у наслову сугерише, представљају само извод из синтаксе, као референтна Новаковићева синтакса обично се узима ова, из 1870. године.

${ }^{3}$ Експлицитни показатељ тог утицаја може се видети у (пуном) наслову Новаковићеве синтаксе из 1869, Срйска синйакса : у изводу за други разред гиманзије и реалака у Кн. Србији (йо Ђ. Даничићу, П. Будману и др. састиавио Сйојан Новаковић). 
и да ли се и у којој мери аутори граматика ослањају на стране ауторе или на претходно објављене српске граматике.

Граматике и студије ћемо приказати хронолошки, по години настанка студије, која се неретко доста разликује од времена првог објављивања 4 . Представићемо и поједине граматике у којима се о синтакси, па и о реду речи, веома мало говори, понегде чак и нимало не говори, а све како бисмо приказали с једне стране континуитет у продукцији граматика и језичких студија, a с друге стране и јасан дисконтинуитет у приступу синтакси и нарочито реду речи као њеном специфичном експоненту. Анализираћемо следеће граматике и језичке студије:

1. Авраам Мразовичъ, Рдководсӣво къ славенсӣбй граммайіus во уйоиребленїе славено-сербскихъ народныхъ училищи, Вїена, 1794.

2. Л Лка Мвшицкий, Нвное исйьийаніе славено-сербскїм граммайіки, Будим, 1802.

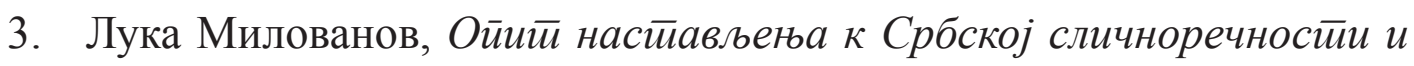
слогомјерју и ӥросодии, Беч, $1833^{5}$.

4. Димитрије Тирол, Славенска грамайика, сад ӣрви ред на Срйском језику изјасьена, Беч, 1827.

5. еюргіл Захарілдис, Славенска граммайіка, Будим, 1832.

6. Милованъ Видаковичъ, Граммайіка сербска или йаче крайкое йо исйыйословію у сербскій єзыкъ Руководсйво, Пешта, 1838.

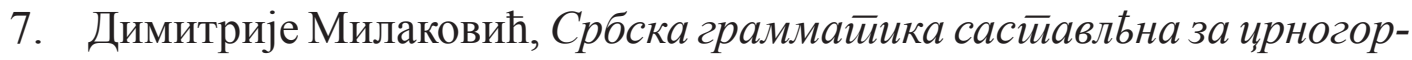
ску младежь, Часйь иррва, Цетиње, 1838.

8. Јован Поповић, Србска граммайіка или йисменицуа, йо начину коимъ найславніи наши Сйисайельи ӣишу, нарочно на ӣолзу ирремиле младежи Србске устироєна, Нови Сад, 1843.

9. Илїя Захарїєвић, Србска граммайика, Београд, 1847.

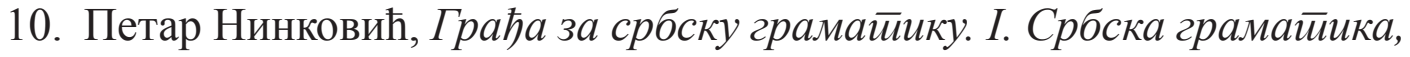
Београд, $1848 .^{6}$

${ }^{4}$ У случају да поједини аутори имају објављене граматике и пре и после 1850 . године, приказаћемо и потоње како бисмо имали поптун увид у ауторове евентуалне синтаксичке ставове.

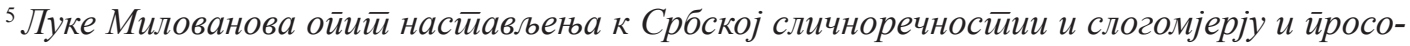
дии. По новом йравойисања начину смайрајући на йовод к новој весма нуждној Србској Писменици или Језикуонауку сйисан 1810. А издао га Вук Стиеф. Караиић. Дело је написано 1810. године па смо га сходно томе тако и поставили у редоследу анализираних студија.

${ }^{6}$ Како бисмо испратили (дис)континуитет у Нинковићевом граматичарском раду, а и како бисмо одговорили на једну од хипотеза рада, анализираћемо и две његове потоње граматике: 
11. Їованъ Балукџићь, Грађа за србску грамайику. II. Теоријско-йрак-

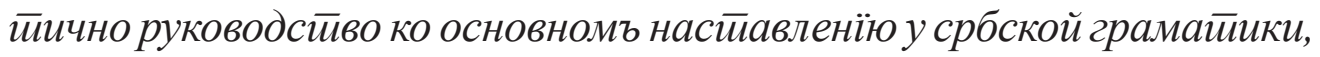
Београд, 1850.

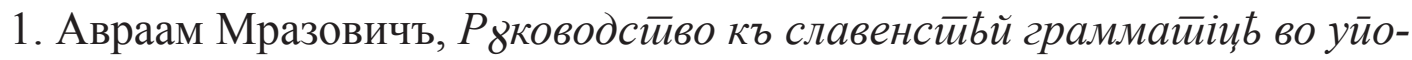
ирребленїе славено-сербскихъ народныхъ училичъ

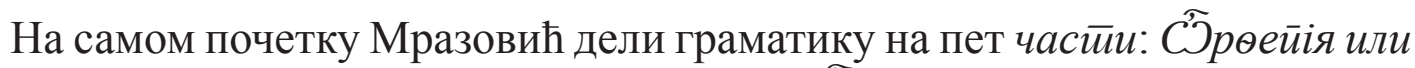
Правоглаголанїе, Просшдїа или Гласовдаренїе, С̂рөографїа или Правоиисанїе, Сөүмологїа или Хддожноиловїе и Сүнйазїсь или Сочиненїе. За синтаксу у

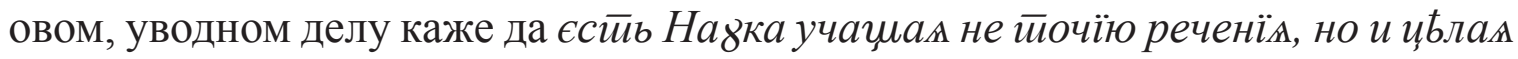
слова сочинАйи, и єдино съ дрдгимъ свґзыввати (Мразовић 1794: 2). У уводу

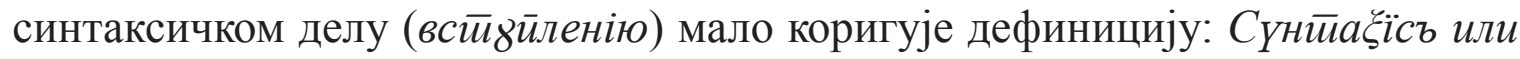

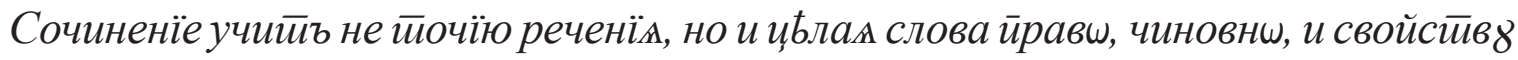
«зыка сходнш свљзыввати (Мразовић 1794: 156). И у првој, а нарочито у другој дефиницији, инсистира се на правилном и аутентичном повезивању реченичних чланова у целине, па бисмо могли очекивати да ће, сходно томе, и карактеристични ред речи бити предмет разматрања у овом делу Руководсйва.

Део о синтакси подељен је на два дела, $G$ сочиненіи скландмыхъ часиеей слова (158-180) и G сочиненіи нескландмыхъ частией слова (180-186). У синтакси променљивих врста речи највећа пажња посвећена је синтакси глагола. Њен завршни, трећи део, GJ чинь глаголшвъ съ ирочими часиими слова (въ совершенныхъ членбхъ) наблюдаемомъ (175-177), посвећен је анализи типичних позиција глагола и глаголских допуна (и других реченичних конституената с глаголом у вези), односно анализи прописаног реда речи у (совершеној) реченици.

У делу $G$ чинь глаголwвъ съ имены и мьстиоименімми разматра се, најпре, позиција и унутарреченични однос именица и заменица употребњених у номинативу (граматичког субјекта) и глагола, односно предиката. На првом месту се истиче да глагол йо болшей часиии именииелному и єму иринадле-

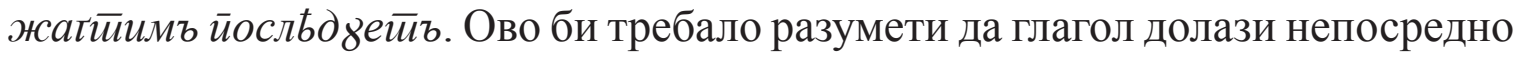
после субјекта (субјекатске синтагме) у реченици, што се може закључити по примерима које даје уз ову тврдњу (Небеса йовьдаюйъ славд Божію.

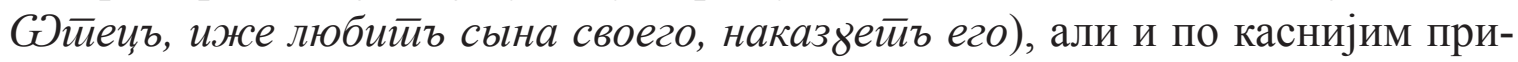
мерима одступања од овог, по Мразовићевом мишљењу очигледно, основног реченичног модела и неутралног реда речи у српској (славенској) реченици. Често померање глагола ка крају реченице (постпонирање) Мразовић налази у примерима након везника и везничких конструкција аще би, аще $u, x о \bar{u}$,

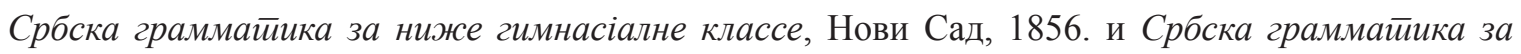
србске нормалне школе, Нови Сад, 1857. 


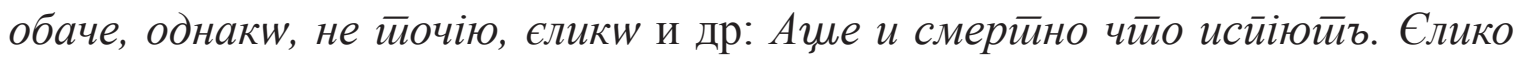
вжұшій еси. Измештање номинатива (граматичког субјекта) са иницијалне позиције у реченици налази у четирма ситуацијама: у упитним реченицама

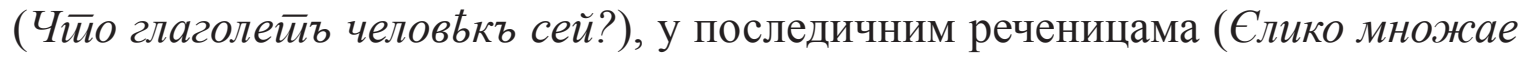

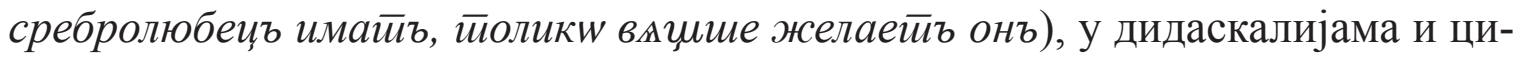

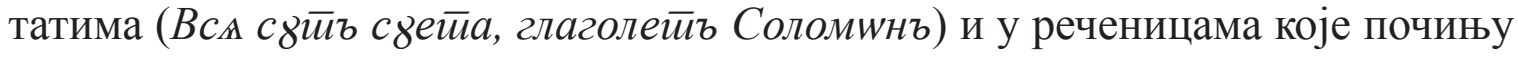
глаголском рекцијом, предлошко-падежном конструкцијом или зависном реченицом (На Крестиь моляше Іисъ за враги своя).

Даље у тексту Мразовић разматра реченице са поливалентним глаголима, те редослед њихових допуна (објеката) у реченици. Тако, када глагол захтева

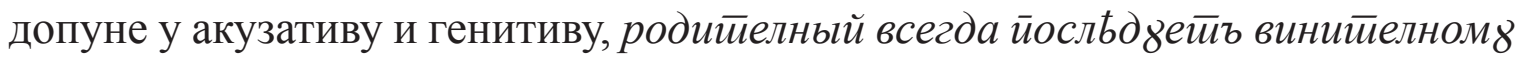
(Не лиши насъ Небесныхъ иввоихъ благъ). Ако, пак, глагол тражи допуне у акузативу и дативу, Мразовић се делимично ограђује и каже да дайелный ио болией частии ирредходийъ винитиелномд (Даждь ми рдкв йомоги), те даје

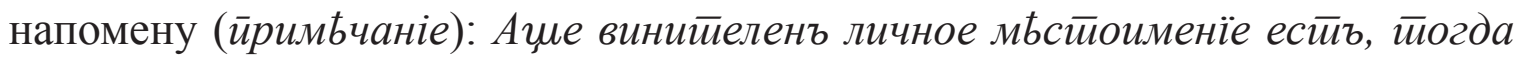

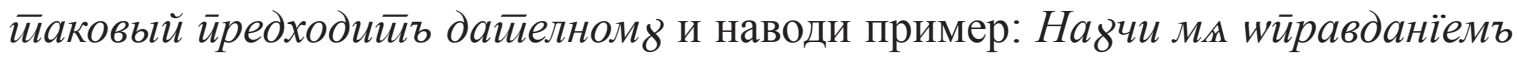
йвоимъ.

$G$ чинь глаголwвъ съ йрочими частими слова доноси осврт на позицију и редослед инфинитива и партиципа у реченици.

А. Когда два гла въ наклоненїи нешпредьленномъ стицаютса; тогда той предходитъ, єм8 же дргїй принадлежитъ : ғако: Повель ми дати ғасти, наше єстъ хотьти творити.

Б. НеwпредЬленное наклоненїе либо причастї^ сл жжать по болшей части къ заключенїю члена ; ғако: Рече же Петръ: Гди съ тобою готовъ єсмъ, и въ темницъ и на смертъ ити. Разбойникъ видъ Началника жизни на Крестъ висАџа (Мразовић 1794: 177).

На самом крају овог синтаксичког поглавља Мразовић како видимо истиче једну од најупечатљивијих и најпрепознатљивијих одлика славеносрпске реченице, а то је постпозиција глагола, и то најчешће инфинитива као неличног дела сложеног предиката. Чињеница да су реченице које наводи као примере стилски изразито маркиране и припадају религијском дискурсу иде у прилог хипотези коју доказујемо у претходно наведеним радовима: постпонирање глагола директна је последица утицаја руског и рускословенског језика и није репрезент синтаксе народног српског говора насловљенога времена времена.

2. Лука Мұшицкий, Нвное исйыйанїе славено-сербскїл граммайіки

У овом осврту на питања из славеносрпске граматаике Мушицки на почетку граматику дели на 5 делова: Словойроизведенїе, Гласоддаренїе, Благогласїе, GӘбазованїе частией слова и Сочиненіее, те наглашава да због недостатка времена намъ же два йосльдня яко нуждньйша ойдьлэнїя ирредметиомъ ученїя 
быстй (Мушицки 1802: 7). Рад би се најтачније дао описати као ауторов попис најзначајнјих питања морфологије и синтаксе славеносрпског језика.

У делу посвећеном синтакси листају се питања посвећена структурносемантичким и структурним особеностима појединих врста речи и њихових спојева као услова за коректну реализацију реченице. Највећим делом ради се о синтакси именица (падежа) и синтакси глагола. Ред речи као синтаксичка карактеристика не помиње се у раду.

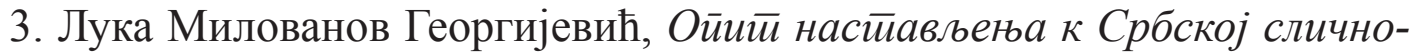
речностии и слогомјерју и йросодии

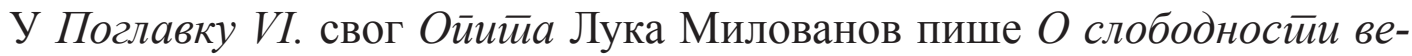
заног сиичса и каже да ауторима стихова треба понекад опростити одступања од граматичких правила јер је стиихойвореи честио усилован од ойшйег йра-

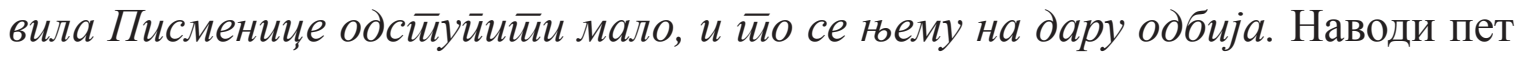
типичних одступања од норме песника тога времена: Скрайња. Продужња. Премейња. Премјена. Вежња.

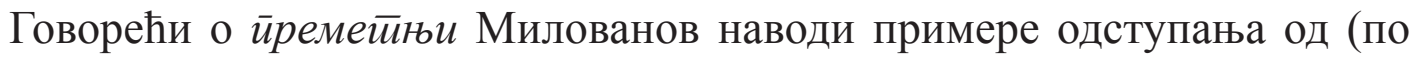
његовом језичком осећају) уобичајеног реда речи у српском језику, а због

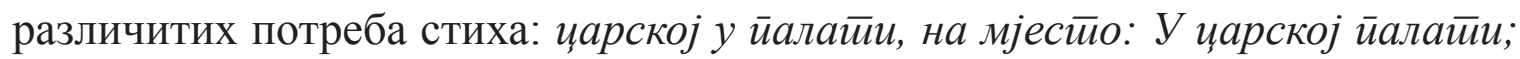
Његово на йрошење, Србског језика на глаголању на мјесиио шито би рећи йребало: На његово иррошење. На глаголању Србског језика. По наведеним примерима види се да је подразумевани неутрални ред речи у српском језику код Луке Милованова 1810. године у великој мери подударан са (тадашњим и данашњим) народним говором и језичким стандардом. Међутим, то би се пре могло везати за његове теоријске ставове или евентуално оивичити на синтаг-

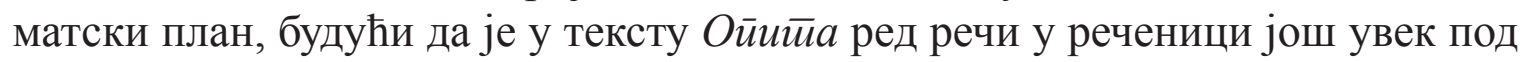
јаким утицајем славеносрпског и рускословенског језика. То се може видети и по цитатима наведеним даље у раду.

Преметњу дефинише као појаву кад се која реч на местио у невезаном сйису, и у обичном са свим необично йостиави и на крају закључује ова и овим йодобна говорења виде се језику Србском ираве нейойребе, који се изван везаног сиичса чуватии ваља (Милованов 1833: 66-70) ${ }^{8}$.

\footnotetext{
${ }^{7}$ В. фусноту 5.

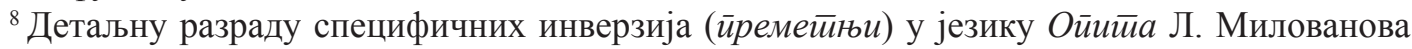
даје Р. Маројевић у раду „Инверзија посесива и предлошко-именичке везе” (Маројевић 2012).
} 
4. Димитрије Тирол, Славенска грамайика, сад ирви ред на Срйском језику изјасњена

Граматика Димитрија Тирола би се по поднасловима које аутор у њој издваја могла поделити на осам (девет) делова. Суштински то су три уже граматичке целине: фонетика и фонологија, акценат и правопис (интерпункцијски знаци и употреба великог слова), и два додатка: примери текстова из раних фаза српског књижевног језика, Доказайелстива из најстиарији Славенски рукойиса, и списак пренумераната.

О синтакси, па и о реду речи у реченици, не говори се у овој граматици.

5. Геюргін Захарілдис, Славенска граммайіка9 .

Аутор граматике је Грк, Георгиј Захаријадис, који је у време објављивања био професор словенске и класичне (грчке) граматике у шабачкој гимназији. Граматику дели на Етимологију или художнословије и Синтаксис или сочињеније. Синтаксички део чине предговор, Предувьдомленіе, и синтаксички опис појединачних врста речи, G сочиненію осамь часиій Слова (Захаријадис 1832: 190-256). За нас је изузетно интересантан уводни део, такође подељен на два дела, $G$ членовыма и $G$ йор дкв рбчій у членовыма. Још на самом почетку првог дела, када аутор дефинише појам синтаксе, сочињенија, можемо уочити да се важност придаје и реду речи као инхерентном синтаксичком параметру, сочиненіе естиь наяка, коя насъ учи единсиввенне рбчи и ибла слова иравю, чиновн (Захаријадис 1832: 190) ${ }^{10}$.

У другом делу, $G$ йорљдкв рбчій у членовыма, Захаријадис најпре даје поделу реченица по комуникативној функцији. Наводи независне,

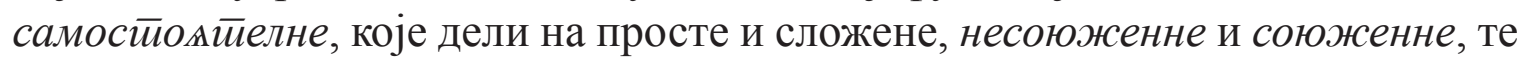

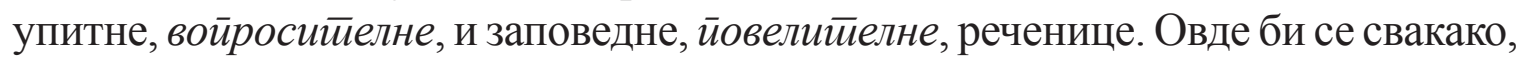
у складу са данашњом терминологијом, али и примерима датим даље у одељку,

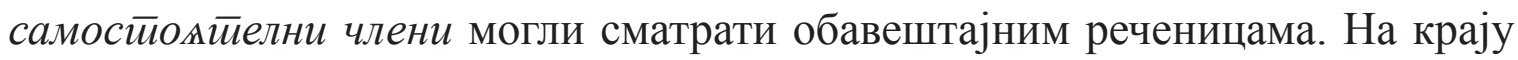
поделе аутор закључује и йо овыма се на тири начина расиолажд и йосльдую рбчи у членв (Захаријадис 1832: 194). У самој анализи дају се запажања о редоследу субјекта и предиката у одређеном типу реченице.

${ }^{9}$ Исти аутор је још 1824. године у Шапцу написао (штампано је 1830 . такође у Будиму) РОКОВОДСТВО къ славенской граммайӥцы, конципирано као скуп правописних упутстава с речником, а намењено ученицима и студентима. Сам наслов ове граматике додатно сугерише на евентуални утицај Мразовићевве граматике на Захаријадисов рад.

${ }^{10}$ На крају овог дела аутор уводи и појам Періодъ, којим дефинише сложену реченицу, специфичну с аспекта информативности исказа, и наводи два различита примера која потврђују тезу да се у таквој вези главне и зависних (побочних) реченица потпуна информативна актуализација постиже тек на самом њиховом крају. 
Просте обавештајне реченице одликује уобичајен ред речи, субјекат

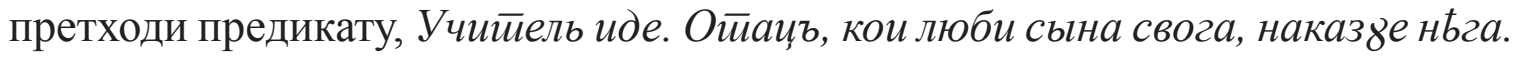
У союженнымъ членовыма йосльдяю рбчи двоякw. После неких везника остаје непромењен ред речи, субјекат претходи предикату. Уз пример Ми неймамо ове године воћа, єрбо мразъ є ивеће убїо, аутор даје и два примера (са везницима но и обаче) који представљају примере независно-сложених реченица. С друге стране после везника (везничких група) акw бы, акw и, кад бы, хой нетиочїю, єликw, и др. аутор као карактеристику реда речи истиче постпонира-

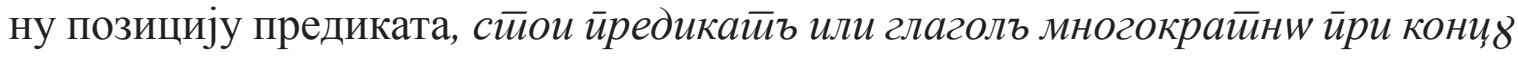
и заключде членъ, уз пример Ако и смритно шито исиїю, неће имъ шкодийи (Захаријадис 1832: 194-195). Уз напомену да се везник обаче налази у обема групама, на основу овакве поделе, можемо претпоставити да аутор наслућује разлику између зависно-сложених и независно-сложених реченица

Код упитних и заповедних реченица у први план истиче постпозицију субјекта ${ }^{11}$ непосредно после предиката, Шйа говори человькъ овай? Узми $\bar{ш} ы$

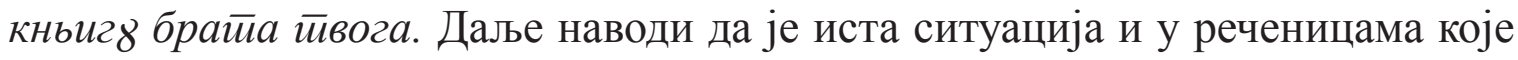
представљају одговоре на питања или се њима цитирају нечије речи, Сва $є с 8$

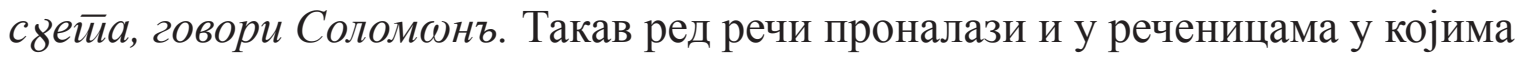
се глаголска рекција (предлошко-падежна конструкција или зависна реченица)

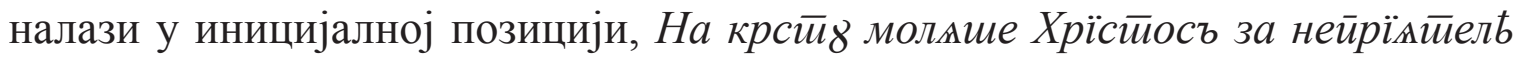
свое (Захаријадис 1832: 195).

До краја овог одељка анализира реченице са поливалентним глаголима и дефинише редослед глаголских допуна. Тако за глаголе који захтевају допуне

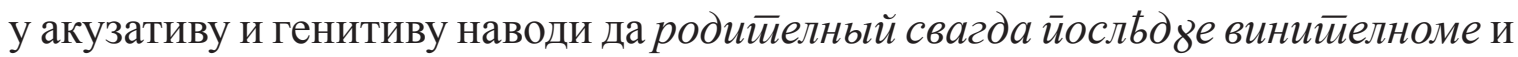

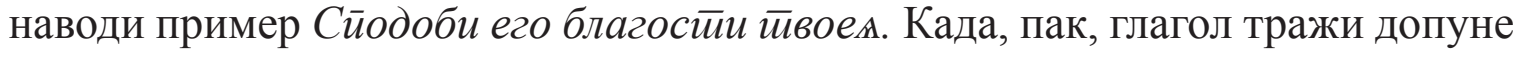
у дативу и акузативу, наводи да датив у већини случајева претходи акузативу,

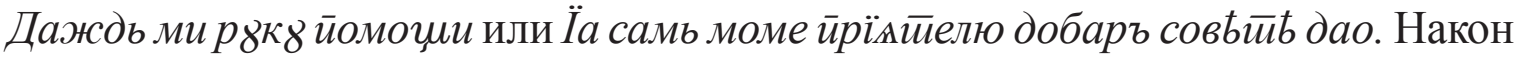
овога даје коментар (иримьчанїе) да акузатив претходи дативу када се у облику акузатива налази лична заменица, Научи мя сирравданїемъ йвоимъ. Оно што ми можемо приметити је да аутор вероватно није свестан утицаја наглашеног или ненаглашеног (енклитичког) облика заменице на њену позицију у реченици. Такође, и сама позиција глагола у другом примеру вероватно утиче на редослед правог и неправог објекта у реченици.

На крају одељка о реду речи Захаријадис експлицира йриродно $u$

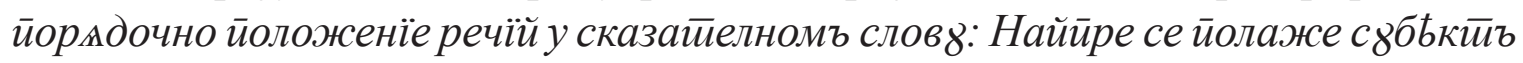

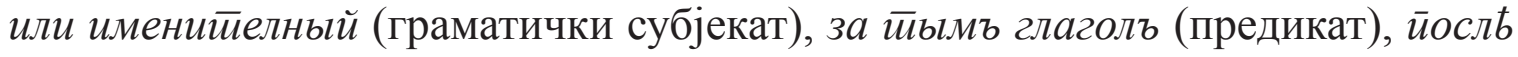
нарьчїе (прилошке одредбе, исказане прилогом претпостављамо), йосль йaдежи, кое глаголъ изыскве (глаголске допуне, прави и неправи објекат), и на

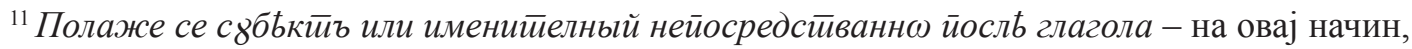
претпостављамо, аутор дефинише граматички субјекат у реченици. 
йосльдакъ ирредлози (прилошке одредбе исказане предлошко-падежним конструкцијама). Након примера реченице која потврђује овакав неутралан ред речи,

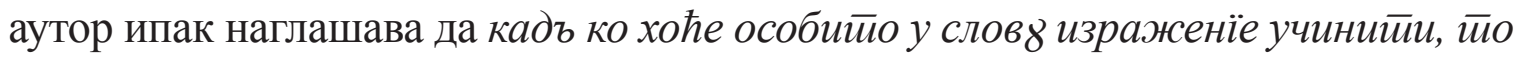

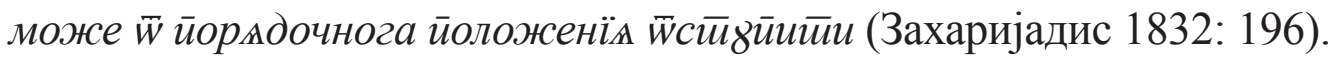

6. Милованъ Видаковичъ, Граммайіка сербска или йаче крайкое йо исйыитословію у сербскій єзыкъ Руководсииво

У петом одељку своје граматике М. Видаковић анализира $C \ddot{\text { vйй } \bar{\xi} и с ъ}$ или сочиненіе слова. У делу о синтакси глагола аутор један део посвећује и анализи реда речи, односно позиције глагола у реченици, $G$ чинд глагола съ ирочими часиими слова, кои су совершены членови наблюдавайы имаю (Видаковић 1838: 167-169).

Овај део аутор дели на два засебна дела у којима говори прво о реченичним односима глагола са именицама и заменицама, а затим и односу глагола са другим врстама речи. Део $G$ чинд глагола съ именми и мбстиоименіями је такође подељен на две целине, по сличном критеријуму као и код претходне поделе: специфичност и заступљеност у језику.

У смойренію йадежа именииеелна представља анализу карактеристичног реда речи када су именске речи (именице и заменице) у форми номинатива. Судећи по примерима, али и по томе што аутор у обзир узима само именице и заменице, можемо закључити да он овде углавном анализира редослед субјекатских и предикатских формација у (простој) реченици. Тако каже да глаголи ионайвише именителному и ему иринадлежащымъ йосльдую. Одступање од уобичајеног распореда аутор налази у четири ситуације: а) код питања: Шӣо говори овай человькъ? б) у управној клаузи зависно-сложених реченица ( $y$

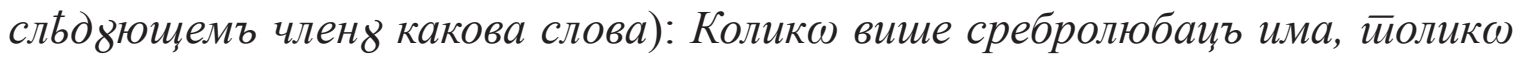
виме жели онъ иматии. в) у реченицама које се односе на нечији (од)говор: Сва

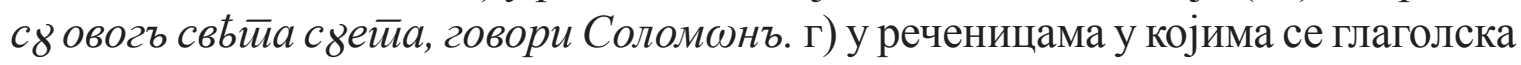
рекција (предлошко-падежна конструкција или зависна реченица) налази у иницијалној позицији: На крестия моляше Јисвсъ за враге свое. У смойренію ирочихъ йадежа представља ауторов осврт на дворекцијске (двообјекатске) допуне глагола. Ако глаголь винииеелный и родииелный йадежь ище, тада увек генитив долази иза акузатива, Не лиши мене милосиии иивоее. Ако ли глаголь

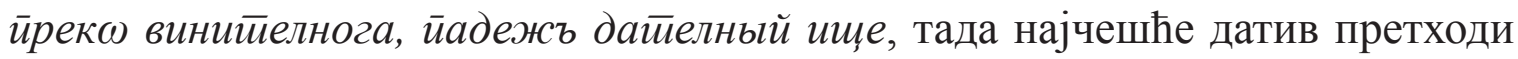
акузативу, Подай рдкв йомощи. Одмах иза тога даје напомену (иримьчанїе) да акузатив (личних) заменица претходи дативу у оваквим реченицама, Научи ме ширравданїю иивоему (Видаковић 1838: 167-168).

Други део, GJ чинв глагола съ иррочими частими слова, доста је краћи и састоји се из две напомене које се тичу неличних глаголских облика, начинъ неюйрьделенный или ирричасииія. Напомиње се да уколико се два нелична облика 
(инфинитива) нађу један за другим у реченици, онда онай глаголь иредходи

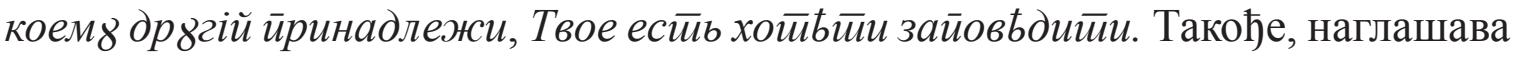
се да су овакви глаголски облици најчешће постпонирани (йонайвише слұже къ заключенію члена), Разбойникъ видь началника жизни на крестия висьћа (Видаковић 1838: 168-169).

Ако узмемо у обзир годину настанка ове граматике, те све наведено у вези са редом речи у њој, намеће нам се закључак да је Видаковић у најмању руку био упознат са садржајем Захаријадисове Славенске грамайике. Синтаксичка запажања, напомене, па и примери који их потврђују безмало су идентични. Ипак, можемо рећи да је узрок томе претпоставка да су и један и други аутор могли имати заједнички узор - највероватније Мразовићево Рдководстиво къ

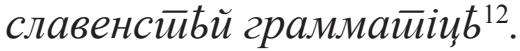

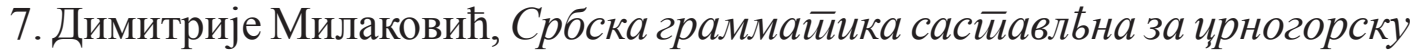
младежь, Частив иррва

Аутор граматику схвата као учење правилног писања и говора и сматра да се она раздґлюе на иири частии кое есу: Словоироизведніе (Ейимологія), Словосочиненіе (Синйаксись) и Правойисаніе (Орөографія) (Милаковић 1838: 1). Раније у Предговору наводи да је ово први део граматике, а да ће друга два дела (синтакса и правопис) бити штампани идуће године. До тога, нажалост, никад није дошло.

8. Јован Поповић, Србска граммайіка или йисменица, ӣо начину коимь найславніи наши Сйисайельи йишу, нарочно на йолзу иремиле младежи Србске устироєна

У предговору граматици посвећеном читаоцима (Предговорь на Чи$\bar{u} a \bar{u} e л ь)$ Поповић наглашава проблем тројаког схватања књивенога језика у Срба у то време и сврстава себе у (трећу) групу аутора чији је став, чини се, био напомирљивији, а који су се залагали за употребу народног говора, али и словенског наслеђа, када год лексичко-граматички фонд народног говора и система не би био довољан. Када наглашава разлоге своје опредељености за такав став, Поповић углавном говори о правопису (Правойисаню) и морфологији (Произведенію), док се синтакса у том контексту не помиње (Поповић 1843: VII-XIII).

${ }^{12}$ Понекад их разликују само различити начин фонетске (графемске) адаптације одређених гласова или различита лексичка прилагођавања, нпр: На Кресӣ

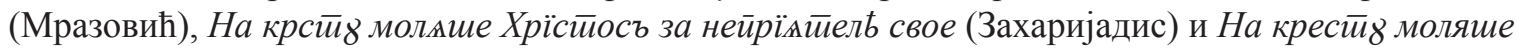
Јисвсъ за враге свое (Видаковић). 
Граматику дели на два дела - граматички (O йравоговореню) и правописни (О йравойисаню). Сам граматички чине три дела - морфологија (словоироизведеніе), којој је у складу са граматичарском праксом тога времена посвећен највећи део књиге (2-106), синтакса (словосачиньніе) и прозодија (слогоудареніе). Део о синтакси такође је подељен на три дела, при чему су прва два дела (О смыслима и Обча йравила Словосачиньнія) општија и сажета (106-110). Трећи део, Особена ирравила, о међусобномъ єдинсиивены рьчій сачиньнію, представља приказ и анализу синтаксе појединачних променљивих и непроменљивих врста речи.

Први осврт на ред речи, као граматичку и синтаксичку специфичност, имамо у делу о синтакси заменица када се објашњава позиционирање енклитичких облика личних заменица унутар реченице.

Мени, йеби, себи, съ тымъ се разликуе одъ ми, $\bar{u} и, c u$, что оно може стояти и само по себи и посль предлога; а ово само предъ, или посль временика, н.п. Коме ћy дайи ову кньигу? Теби, а не $\bar{u} и$. Я сам $\bar{u} и$ казао да дођешъ къ мени, а не ми. (Поповић 1843: 117)

У делу о синтакси глагола, О сачинбнію временика, даје се посебан осврт на позицију глагола у конструкцијама са појединим врстама речи, $O$ йоредку временика, кой се съ ирочима частима слова, у смойренію савршены членова, наблюдаваии иора. Он је начелно подељен на део који се бави прописаним редом речи у односу глагола и именских речи и део у којем се прописује ред речи у односу глагола и осталих (променљивих) вртса речи ${ }^{13}$.

У делу $O$ йоредку временика са Именма и мьсиооменіяма наглашава се постпозиција глагола у односу на граматички субјекат, односно у односу на именске речи и синтагме исказане номинативом, сви временицы, йо већой частии Именителном, и ньму иринадлежећимъ рбчма йосльдую. Аутор наводи четири случаја када се одступа од таквог реда речи у реченици: у упитним

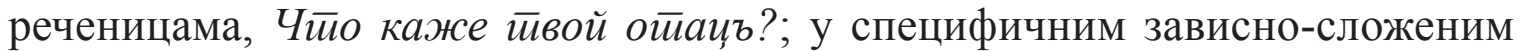

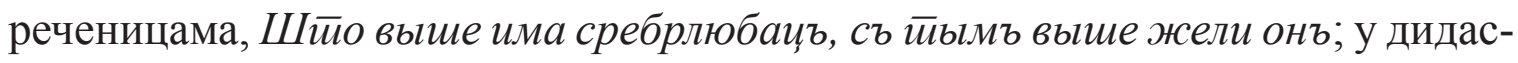
калијама управног говора или цитатима нечијих мисли, Све $\epsilon$ земно суєй $a$, говори Соломонъ и у ситуацијама када реченица почиње објектом или адвербијалном одредбом или допуном, Не мене, но иеебе є увредіо брайъ йвой. У истом одељку говори се и редоследу глаголских допуна када су у питању поливалентни глаголи. Тако, за примере када глагол захтева допуне у генитиву и акузативу, прописује употреба генитива после акузатива, Сйодоби га (удосйои га) Боже Милостии иивоє. Када глагола захтева допуне у дативу и акузативу, каже се да датив чешће претходи акузативу, Дай ми руку йомоћи. Другачији

${ }^{13}$ Овде можемо констатовати сличан степен подударности синтаксичких ставова, напомена и примера са граматиком Г. Захаријадиса као и код М. Видаковића. Као и тада, и овде ћемо се оградти претпостављеном заједничком узор-граматиком. 
распоред допуна аутор налази у примерима када је директни објекат исказан личном заменицом, Онъ йе є обявіо народу.

У делу О йоредку временика съ иррочима скланяємыла часйма слова разматра се позиција инфинитива и глаголских прилога (партиципа) у реченици. Наглашава се њихова веома честа постпонираност, истиче се да они служе йонайвыше къ заключенію члена. Када се два глагола у инфинитиву нађу у реченици, йо онай ӣредходи, коме другій иринадлежи, прописује аутор и

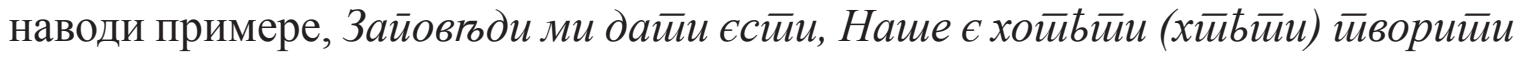
добро (Поповић 1843: 124-126).

9. Илїя Захарїєвић, Србска граммайика

Србска е Граммайика наука, коя изяснява, ӣравила йо коима Србски

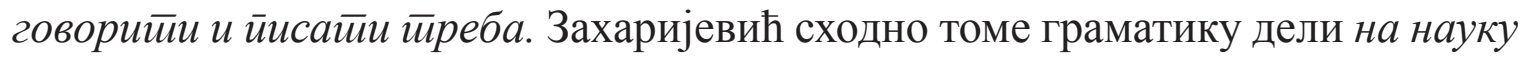
ирравоговореня, и науку йравойисања. Први део граматике, пак, дели на йри разделька: Словоисйыйивань, словосочиненіе и словоудареніе (Захаријевић 1847: 1).

Словосочиненіе, синтакса, приказана је у трећем раздельку (75-100) који отпочиње дефиницијом:

Словосочиненіе содржава правила показуюћа, како части слова т.е. речи међу собомъ свезивати треба, да изъ ньи валянъ говоръ постане. И тако е словосочиненіе Србско наука. коя показуе правила, како речи Србске међу собомъ свезивати треба, да валянъ говоръ Србскій постане (Захаријевић 1847: 75-76).

Подељен је на два основна дела - обийа и особийа иравила словосочиненія, при чему се у првом, краћем, делу дају опште дефиниције синтаксичких чинилаца, просте и сложене реченице (иростио и сложено изреченіе)

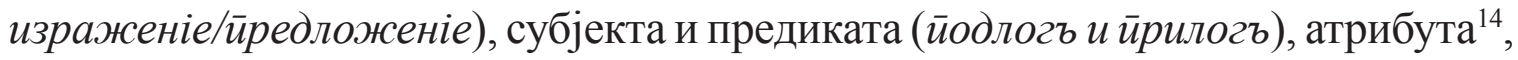
падежа...

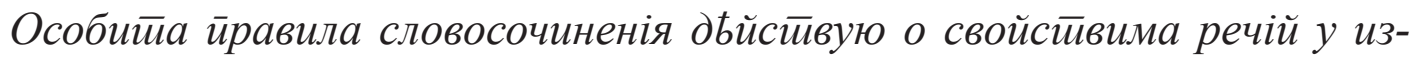
раженіяма, о йоредку речій, и о скрайньи иредложенія (исто: 79) - као што видимо на самом почетку, дефинишући 'посебна правила синтаксе', аутор показује да ред речи сматра инхерентним делом синтаксе једнога језика, и посвећује му значајну и засебну пажњу у овом одељку.

Део О йоредку речій (93-97) конципиран је тако да се у засебним поглављима разматрају правила о реду речи карактеристична за појединачне врсте речи. Ипак, пре тога се у виду одговора на питање Шйа е йоредакъ? - даје својеврсна дефиниција појма ред речи: Поредакъ речій есӣъ наука йоказуюћа,

${ }^{14} \mathrm{He}$ даје конкретну дефиницију (конгрунтног) атрибута, али каже: Прилагайелна, броииелна, мьстиоименія, иричасиія свойстиво ирилагайелны имаюћа слажу се са своимъ сушчестивителнымъ у роду, брою, и йадежу (Захаријевић 1847: 78). 


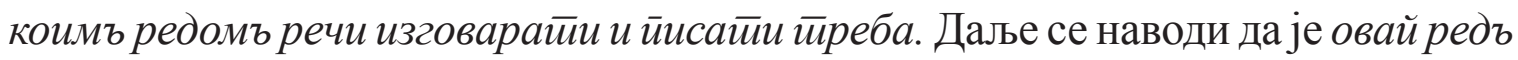

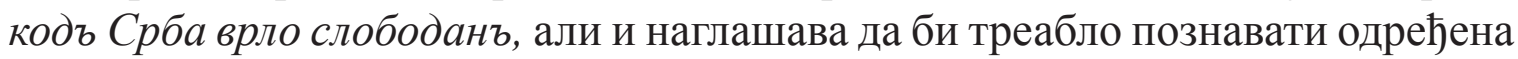
правила (о реду речи) о појединим врстама речи у српском језику.

У првом делу расправља се о именицама и наводи да се именица у номинативу увек поставља на почетак реченице (Пейарь чий $a$ ), да се у реченицама у којима глагол захтева две именице у номинативу једна поставља на прво, а друга на последње место у реченици (Іованъ е ученикъ), као и да се гди се двоуміе збогъ именииеелногъ и винииеелногъ йадежа рађа, йу увек именииеелный

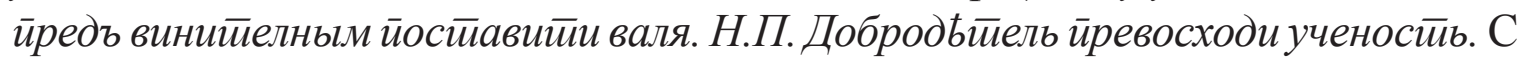
аспекта савремене граматике речено, граматички субјекат најчешће се налази у иницијалној позицији у реченици, именски предикатив пак у финалној, док се у реченицама са прелазним глаголом, граматички субјекат употребљава пре директног објекта.

У наредном делу о придевима и партиципима ${ }^{15}$, на почетку се наводи да се придеви йо већой часйи употребљавају испред именице (Добра воћка лейь илодъ ириноси). Експлицирају се три ситуације када је антепозиција придева обавезујућа: када се у истој атрибутској позицији уз придев употребљава и присвојна заменица (Ово е кньига могъ найвећегъ иріяиеля), ${ }^{16}$ када је придев у суперлативу (Онъ е найсреитніи човекъ), те кад придеву претходи (општа заменица) савъ, сва, све ( аутор наглашава да су придеви обично постпонирани када је њима исказана титула (Душанъ Силнылй, Карль Великій), те да у реченици придеви могу бити удаљени од своје именице ${ }^{17}$ (Красне и вкусне у нашой башиии растиу ябуке), као и да за партиципе важе слична правила као и за придеве (Изгорела е куйльна кућа, или: изгорела је кућа куйльна).

У делу о бројевима наводи да се основни бројеви йолажу ире сииварій коима йринадлеже, док за редне наглашава да имаю свойсивво йрилагайелны, шйо се реда у говору иичче. На крају овог одељка, аутор прописује ред речи код исписивања целих бројева, односно конструкција (основног) броја и (децималног) дела йо (разбіеніе): онда се броени новци између целогъ и разбіенія иолажу, а сиивари се йостиавляю иоосле иелогъ и разбіенія. Н.П. Я имамъ иеейъ гроша и йо. Я самь куйіо оку и йо млека.

${ }^{15}$ Мисли се заправо на конгруентни атрибут, али ћемо у тексту рада оставити придев односно партицип како би се следила планирана композиција овог поглавља Захаријевићеве граматике.

${ }^{16}$ Прилично неочекивано правило ако се узме у обзир да се у великом броју граматика написаним пре ове, али и оним које су написане након 1847. године, као најчешћи пример постпонираног конгруентног атрибута узимају управо посесивне речи (присвојни придеви и заменице).

${ }^{17}$ Мисли се на центар (именичке) синтагме. 
Личне заменице се (у функцији субјекта) употребљавају испред глагола, осим ако найредъ нарьчіе или союзъ несйои, и ако се нейытйа. Енклитички облик датива личних заменица употребљава се у реченици ипред енклитичког облика акузатива, Дай ми га. За односне заменице Захаријевић наглашава да се увек налазе на почетку (зависне) реченице - израженія - и да захтевају да се глагол позиционира на крај те реченице, Земльдблацъ, кои свою землю добро ради, ужсива велико задовольсииво. За показне и присвојне заменице наводи се да се у реченици понашају као и придеви.

За глаголе (предикат) се наводи да им је позиција слободна, односно да могу стајати и пре и после субјекта (йодлога) у реченици. Издвајају се примери обавезне постпозиције када се испред предиката налази лична или односна заменица, Човекъ, кои говори. Я радимъ. Када је глагол у форми императива, честа је његова употреба у иницијалној позицији, ако се снага говора на другу речь нейолаже. И на крају, прописује се позиција глаголских енклитика, увекъ иосле ирве речи, была ииа речь глаголь, или друга коя часйь говора. Н.П. Онъ е мене йомагао. Учиніо си добро.

За прилоге (прилошке одредбе и допуне) се каже да обично претходе глаголу, али се препоручује постпонирање када је глагол у форми императива. За прилошке интензификаторе се прописује антепозиција у односу на придев који одређују, Петиаръ е у овомъ йослу врло лейъ иримерь ученищыма дао. Предлозима се прописује позиција йредъ своимъ йадежима, изузев предлога 'ради' који може и йре и йосле свога йадежа сйаяйи. Такође, наглашава се њихова интерпозиција у примерима сложених одричних заменица, Нейреба ни у чіой кући викайи.

Говорећи о везницима и њиховој реченичној позицији, Захаријевић углавном разматра зависне везнике и прописује им иницијалну клаузалну

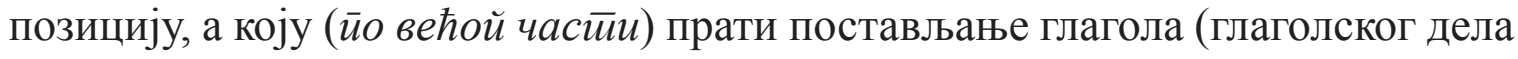
предиката) на последње место у њој, Я самь чуо, да ће йвой ойацъ доћи. Интересантно је да ауотр упитну речцу 'ли' посматра као воиросииеллный союзъ, те је, као и глаголске енклитике, поставља непосредно након прве (наглашене) речи у реченици. За узвике се кратко и јасно каже да се на свакомь местиу уйойребитии могу. ${ }^{18}$

18 Завршни део првог дела граматике (правоговореня) аутор назива $O$ скрайньи йредложенія (97-100). У њему се прилично детаљно приказују и објашњавају различити примери елидирања унутар сложене реченице, те као такав може бити веома интересантан и с аспекта расправе о реду речи у реченици, али ћемо те Захаријевићеве ставове разматрати другом приликом. 


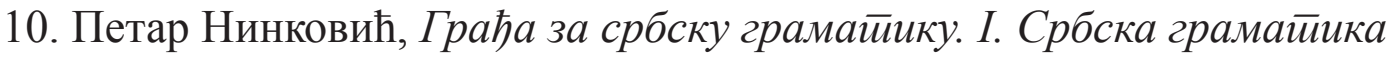

На самом почетку свог Увода у србску граммайику ${ }^{19}$ даје се подела граматике на четири дела, правилно писанье и читанье, етvмологію (корени-

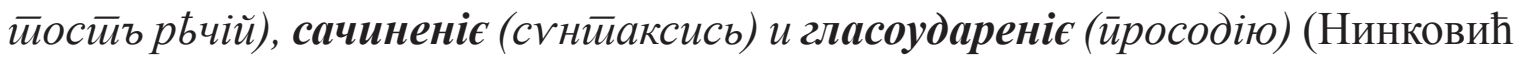
1848: 5). Део о синтакси аутор почиње својеврсном њеном дефиницијом, где каже да сачиненіс учи не само йоедине рьчи, него и йбле слогове йравилно и йо свойстиво и духу езыка сачиняватии и йымь начиномь разумь и смисао ньинь дознаватии (Нинковић 1848: 94). Он је суштински конципиран даље као преглед (морфо)синтаксе појединих врста речи и у њему се не говори посебно о реду речи, али се ипак унутар тих поглавља могу пронаћи одређене сугестије о овој синтаксичкој манифестацији (српског) језика.

Говорећи о синтакси именица (падежа), конкретно о употреби генитива, Нинковић наглашава да кадъ се два или више сушиеесв. имена у едной мысли стиичу, и едно друго не изяснява, онда друго име долази у Род. йадежь, н. йр. Любитель науке. Покровитель ббдны и невольны (Нинковић 1848: 95). Могло би се, можда, дискутовати да ли се ова језичка сугестија може коментарисати када се говори о реду речи. Међутим, ако се узме у обзир да се у великом броју случајева управо ове синтагме у језику писаца тога времена „славизирају” по моделу падежни атрибут(и) испред центра синтагме у реченици, па бисмо имали науке любииель и ббдны и невольны йокровителе, свакако се намеће закључак да овакав ауторов став треба разумети не само као приказ одређеног типа генитива, већ и као експликацију синтагматског реда речи, усклађеног с духом српског народног језика и надолазећег језичког стандрада.

Индиректно се о реду речи говори и у сочиненію мьстиоименія. Нинковић указује да се наглашени облици личних заменица употребљавају на почетку реченице, иза предлога (где наводи и примере за енклитичке форме после предлога, за $\bar{ш} е$, за ме) и када је реченични акценат на њима, кадъ е на ньему сила говора. За енклитике пак наводи да се употребљавају обычно йосле едне

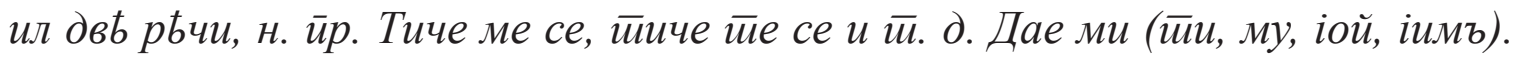
Гледам теме (га, е, іи) (Нинковић 1848: 99-100).

У делу о синтакси глагола аутор набраја примере глаголских рекција, као у неким претходним граматикама, али, за разлику од њихових аутора, само на једном месту даје пример поливалентног глагола, па стога немамо део који би се односио на редослед глаголских допуна, као још једном индикатору специфичног реда речи одређеног језика, односно језичког регистра.

${ }^{19}$ Аутор је недоследан у употреби различитих облика фонолошке адаптације термина гра-

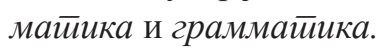


11. Петар Нинковић, Србска граммайика за ниже гимнасіалне классе

12. Петар Нинковић, Србска граммайика за србске нормалне школе

У Србској граммайици из 1856. године Нинковић наводи да је она сачињена на основама граматике објављене осам година раније, те да је знаменитио умножена, усавршена, и гойово рећи сасвимъ ирерађена съ додайкомъ иравойиса (Нинковић 1856: IV). Међутим, за разлику од претходеће граматике у овој се аутор не бави синтаксом, иако је у самом уводу помиње, делећи грамитику 1-во на говорне звуке и слова, 2-го на рбчи, 3-ће словаосачиненіє или слогъ, 4-йо на гласоудареніс (Нинковић 1856: 1). Након кратких напомена о графији и фонетици, долази централни део о морфологији, те на крају поменути правописни додатак.

Нинковићева Србска граммайика из 1857. године не доноси ништа ново када је у питању обрада синтаксичких тема. И за њу се може рећи да углавном даје приказ морфолошке слике српског језика, уз правописни додатак на крају. Једино што бисмо могли издвојити, јесте напомена (примьтба) коју аутор даје када говори о једном типу перфекта: йомажућій глаголь у ирошастиомъ сложеномь времену у иирећемъ лииу ед. бройа свагда, а у множ. брою честио се избаиуе, као: шима се сбыло? Шйа се догодило? Она се учининла да є болестина. Навикли су се, или: навикли се на йосао, и $\overline{\text {. }}$. . (Нинковић 1857: 67).

На крају, интересантно је приметити да се Нинковић у првој својој студији бавио и синтаксичким проблемима нашега језика, што, пак, није случај са граматикама писаним осам, односно девет година касније. Потенцијалних разлога је више. Селидба из Београда у Нови Сад је могући узрок, само под претпоставком да се синтакса у Београду чешће изучавала (али тек касније, Даничић 1858. или Бошковић 1864), а да се у новосадској језикословној пракси њој придавао мањи значај. Наравно, све то и остаје само претпоставка, за чије разрађивање у овом раду нема простора.

Извеснији разлог можемо наћи у чињеници да се у уводу своје прве граматике из 1848. Нинковић оградио да ће о етимологији, односно морфо-

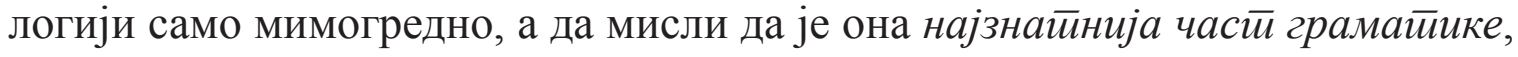
те да се њоме баве највећи словенски лингвисти тога времена. Управо због тога можемо претпоставити да је инсистирање на исцрпности дела о морфологији, те увођење додатка о правопису као граматичарског новитета (као аутор каже), условило изостанак дела посвећеног синтакси у двема потоњим граматикама.

Такође, индиректне поводе за изостанак дела о синтакси можемо пронаћи у насловима трију граматика. Тако у првој видимо да је то грађа за српску граматику, док су две потоње циљно прецизно дефинисане и упућују на одређени ниво школског (гимназијског) образовања. Прва граматика пред- 
ставља само увод у србску грамайику, па се можда због тога у њој претресају сви њени делови, док се у наредним двема, детаљније, анализира оно што аутор сматра битнијим и дидактички сврсиходнијим за граматику тога типа. Претпоставимо да аутор сматра да синтакса није нешто што би требало да се проучава на том ступњу образовања, те јој услед тога не посвећује пажњу у граматикама - уџбеницима.

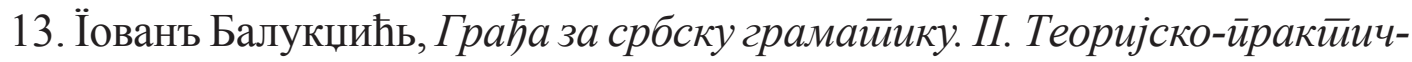

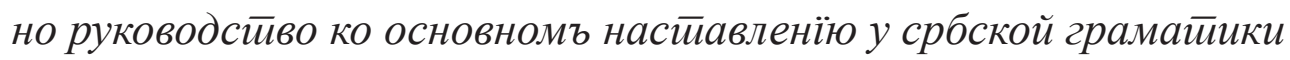

Аутор се у овој монографији не бави синтаксом, већ настоји, како у поднаслову и наводи, да сачини практични приручник за наставу српскога језика, и то на осоновошколском нивоу. Могао би се окарактерисати као спој уџбеника и вежбанке из морфологије (морфосинтаксе) и творбе речи српског језика за основну школу.

За нас је свакако вредна напомене ауторова намера да пише народним језиком, коју износи у уводу своје граматике:

Будући да се овде нећемо упиняти, да страный кои езыкъ учимо, него онай, кога србско дете, као езыкъ ньгове матере, и изъ обичногъ разговора доста већъ зна; то ћемо ученицыма овай сувопаранъ предметъ с тимъ олакшати, ако іймъ свакомъ приликомъ познати дамо, да они и безъ свега изъ обичногъ разговора то знаду, и да ће они само оно, што іймъ се у обичномъ разговору замршено чини, раззазнати, а и о ономъ, кое они готово већъ знаду, овимъ краткимъ коя ће следовати правилама, іошъ боль увђрити се (Балугџић 1850: 1).

Балугџић, како се и види по овом цитату, у целокупном тексту граматике заиста настоји да пише народним језиком. У великој мери у томе и успева, мада се управо у карактеристичном реду речи у реченици његов научно-методички језик неретко удаљава од народског језика и од претпостављеног неутралног реда речи у њему. Потврду да аутор ипак влада и тим аспектом народног језика налазимо у дидактичким примерима које даје читавим текстом приручника: Мала се деца ране сладкимъ колачомъ; У виноградъ свак'

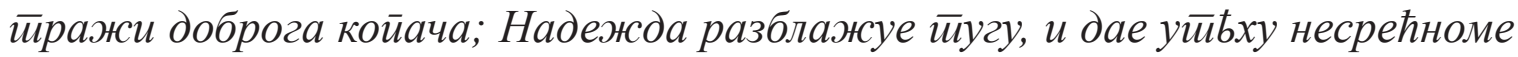
човеку. Може се дискутовати о томе колико су ове конструкције окамењене и у којој мери њихова дужина утиче на једностванији - народски израз, али у већини примера глагол није постпониран, а и синтагматске инверзије, чак и код посесивних речи, ретке су ${ }^{20}$.

${ }^{20}$ И међу дидактичким примерима могу се забежити реченице са славизираним редом

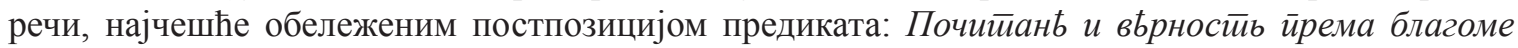
князу у сриу имаймо; Дунавомъ млоге лађе съ воћемъ и солю найоварене иролазе. Верујемо да је ове примере аутор сам конструисао, те да је то претпостављени разлог оваквог реда речи. 


\section{ЗАКљУЧАК}

Већ овај невелики осврт на наше граматичарске почетке наводи на неколике јасне закључке. Нажалост, опште је место, као што смо и у уводу рада нагласили, да се синтакси не посвећује адекватна пажња, односно да се, ако се о њој и пише, по правилу налази у извесном запећку у односу на делове посвећене фонетици и морфологији (понегде чак и делове о правопису).

Даље, у студијама о синтакси у анализираним граматикама ред речи, као специфични синтаксички експонент (славеносрпске) епохе, није у потребној мери заступљен, односно не указује се у њима довољно на његове најпрепознатљивије манифестације. Када се и расправља о реду речи, чешће се говори о карактеристичном редоследу глаголских допуна и позицији субјекта у различитим типовима реченица (Мразовић, Захаријадис, Видаковић, Поповић), него о атрибутској инверзији и постпозицији (дела) предиката као синтаксичким маркерима славеносрпског дискурса.

Чинило се да заокрет у том смислу представља Захаријевићева граматика из 1847, међутим, преостале анализиране потоње граматике у овом раду (Нинковић, Балугџић), као и граматике објављене након 1850. године, а чију ћемо анализу изнети у следећим радовима, показују управо супротно. Ред речи као синтаксичка карактеристика језика тога времена апсолутно престаје да буде предмет анализе у синтаксичим деловима у њима, па чак и у монографијама посвећеним искључиво синтакси (Даничић, Бошковић, Новаковић, Живановић) $)^{21}$. Разлоге томе можемо евентуално наћи у поразу славеносрпског књижевнојезичког модела и победи Вукове реформе, васпоствљању народног језика и његових синтаксичих формација на место језика - узора, те чињеници да је природан ред речи, у великој мери подударан са данашњим, већ постајао свеприсутан у лепој књижевности и новинском језику у њихово време. Ипак, продукција књига писаних славеносрпском синтаксом и даље је велика, а унутар научног стила језика аутора граматика и језичких студија, чак и дидактичких примера у њима, и даље је велики број славеносрпских синтаксичких карактеристика.

Као други претпостваљени разлог оваквом стању у нашим граматикама за анализирани период намеће се специфично - класично образовање аутора, на првом месту Аврама Мразовића, затим и Георгија Захаријадиса, Милована Видаковића и осталих, те развијеност синтаксичких разматрања у класичним језицима. Продукција граматика класичних језика, а тиме и студија о синтакси грчког и латинског језика, у том периоду је на изузетном нивоу, и те студије

${ }^{21}$ И сам Стојан Новаковић указује на недостатак радова на тему реда речи у, на почетку рада поменутом, делу посланице Српској краљевској академији из 1888. године. 
представљају узор и свим другим (европским) језицима у периоду романтичарских тежњи за (ре)дефинисањем нација, између осталог, и преко језика.

Осим препознатљивог класичног образовања, оно што повезује по том питању издвојене ауторе јесте евидентан и јак међусобни утицај. Може се расправљати да ли је то директни утицај непосредних претходника или заједнички утицај једног, најранијег, аутора (Мразовића у нашем случају) на граматичке следбенике - дидактички примери у њима недвосмислено потврђују њихову изразиту повезаност. Отворена је и могућност да је иста страна граматика или студија била узор (директно или индиректно) свима њима, али их поменути дидактички примери, уско везани за српско културно (религијско) наслеђе ипак јаче наслањају на домаћег аутора (или преводиоца).

Ваља нагласити, такође, да су и у језику аутора који су с правом истицали атрибутску инверзију и глаголску постпозицију као специфичности књижевног језика епохе, те наглашавали њихову неприхватљивост када је у питању српски народни (књижевни) језик (И. Захаријевић, касније Е. Јовановић, Ј. Поповић и други), управо ти славеносрпски обрти и даље прилично фреквентни. Тачније, научни стил којим су поменути аутори писали граматике не подудара се са језиком дидактичких примера које у њима наводе, као ни са, неретко јасно експлицираним, ставовима о неутралном, односно природном реду речи у српској реченици (види Матић 2018: 499).

На крају треба издвојити Ойит̄ Луке Милованова и, ма колико се у њему мало говорило о реду речи као синтаксичком експоненту, истаћи да је то прва студија у којој се дефинише неутрални - природни ред речи у српском језику и да се одступања од таквог реченичног модела коментаришу па и одобравају искључиво са стилистичког аспекта, те да ова и овим йодобна говорења (одступања) виде се језику Србском йраве нейотиребе, који се изван везаног сйиса чуватии ваља (Милованов 1833: 68). Први који ће после Милованова реду речи приступити и са синтаксичког и са стилистичког аспекта је Евгеније Јовановић, укратко, на петнаестак страна у граматици из 1851. године, да би тек Пера Ђорђевић 1898. године у приступној академској беседи детаљно анализирао ред речи и представио га као инхерентан и важан синтаксички и стилистички репрезент српског књижевног језика. 


\section{ИЗВОРИ}

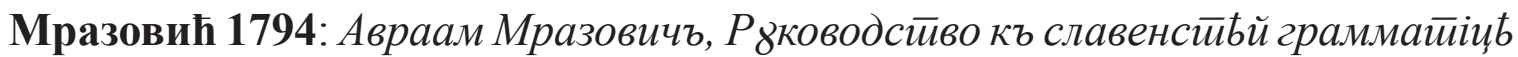
во уйотиребленіе славено-себскихъ народныхъ училищъ, Вїена: түпомъ г. Стефана Новаковича.

Мушицки 1802: Лука Мфшицкий, Нвное исйыйанїе славено-сербскї̈ граммайіки, Будим: Писмены Кральвскога Всебчилиџа Пештанскога.

Милованов 1833: Лука Милованов, Оиичй настиављења к Србској сличноречностии и слогомјерју и йросодии, Беч: Штампарија јерменског манастира.

Тирол 1827: Димитрије Тирол, Славенска грамайика, сад йрви ред на Срйском језику изјасњена, Беч: Штампарија јерменског манастира.

Захаријадис 1832: ГеюргіА Захарілдис, Славенска граммайіка, Будим: Писмены Кральвскога Всебчилича Пештанскога.

Видаковић 1838: Милованъ Видаковичъ, Граммайіка сербска или йаче крайкое йо исйытиословію у сербскій єзыкъ Руководстиво, Пешта: Писмены Іос. Баймела, Острогонскогъ Кньигопечателя.

Милаковић 1838: Димитрије Милаковић, Србска граммайика сасйавльна за ирногорску младежь, Частиь йрва, Цетиње: у кньигопечатньи Правиткля Црногорскога.

Поповић 1843: Јован Поповић, Србска граммайіка или йисменица, йо начину коимь найславніи наши Сйисайельи ӣишу, нарочно на йолзу ӣремиле младежи Србске усироєна, Нови Сад: Писмены Катаріне Іанковића Удове.

Захаријевић 1847: Илїя Захарїєвић, Србска граммайика, Београд: У Правителственной Кньигопечатньи Княж. Србскогъ.

Нинковић 1848: Петар Нинковић, Грађа за србску грамайику. I. Србска грамайика, Београд: Друштво србске словесности.

Нинковић 1856: Петар Нинковић, Србска граммайика за ниже гимнасіалне классе, Новои Сад: Трошкомъ Ігнята Фукса, кньиговезца и кньигопродавца.

Нинковић 1857: Петар Нинковић, Србска граммайика за србске нормалне школе, Новои Сад: пачатано брзотискомъ І. каулиціє.

Балугшић 1850: Їованъ Балукџићь, Грађа за србску грамайику. II. Теоријско-

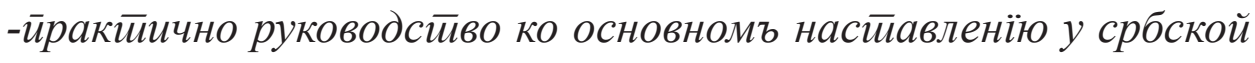
грамайики, Београд: Друштво србске словесности. 


\section{ЛИТЕРАТУРА}

Бошковић 1864: Јован Бошковић, Извод из срӣске грамайике, књига друга, IV.

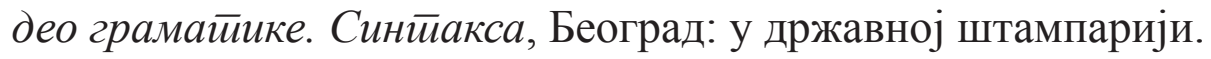

Даничић 1858: Ђуро Даничић, Србска синйакса. Део ирвый, Београд: У државной штампаріи.

Ђорђевић 1898: Пера П. Ђорђевић, О реду речи у српском језику (приступна академска беседа), Глас Срйске краљевске академије, LIII, $167-231$.

Живановић 1889: Јован Живановић, Срйска синйакса, Нови Сад: Издање и штампа А. Пајевића.

Ивић 1971: Павле Ивић, Срйски народ и њихов језик, Београд: Српска књижевна задруга.

Ивић 1991: Павле Ивић, Доситејевски књижевни језик између славеносрпског и вуковског, Научни састианак славистиа у Вукове дане, $19 / 2,5-14$.

Јовановић 2013: Јелена Јовановић, Лингвистиички и стиилистиички асиеккими ироучавањ реченице, Београд: Научно друштво за неговање и проучавање српског језика.

Јонке 1963: Ljudevit Jonke, O redu riječi sa sintaktičkog i stilističkog gledišta u hrvatskosrpskom jeziku, u: Zbornik u čast Stjepana Ivšića, Zagreb: Hrvatsko filološko društvo, 171-182.

Ковачевић 1991: Милош Ковачевић, Из проблематике развоја синтаксичких категорија: финалне конструкције у Доситејеву језику, Научни састианак славистиа у Вукове дане 19/2, 69-80.

Ковачевић 2002: Милош Ковачевић, Синйаксичка негаџија у срйскоме језику, Ниш: Издавачка јединица Универзитета.

Ковачевић 2012: Милош Ковачевић, О граматичко-стилистичком терминосистему туђег говора, Срйски језик, Сйудије срйске и словенске, XVII, 13-38.

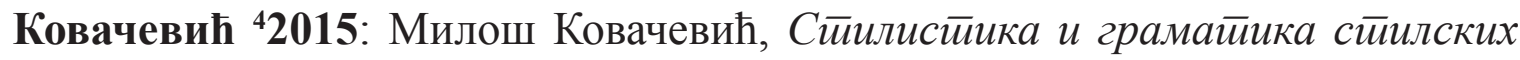
фигура, Београд: Јасен.

Ковтунова 1969: Ирина Илынчина Ковтунова, Порядок слов в русском литее-

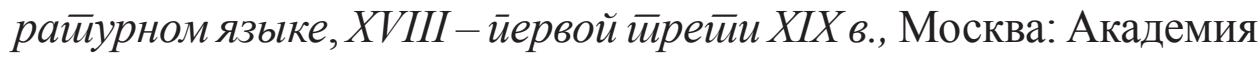
наук СССР, Институт русского языка.

Маројевић 2012: Радмило Маројевић, Инверзија посесива и предлошкоименичке везе (и израз „салтани за землями”, у Слову о йолку 
Игореве), Зборник Мат̄ище срӣске за филологију и лингвисииику $55 / 1,105-120$.

Мацановић 2018: Ана Мацановић, Језикословна террминологија у 19. веку, Београд: Институт за српски језик САНУ.

Милановић 2013: Александар Милановић, Језик весма иолезан, Београд: Друштво за српски језик и књижевност Србије.

Милановић 2014: Александар Милановић, Језик Јована Субойића, Београд: Филолошки факултет.

Младеновић 1989: Александар Младеновић, Славеносрӣски језик, Нови Сад: Књижевна заједница Новог Сада.

Новаковић 21870: Стојан Новаковић, Срӣска синӣакса. За ниже гимназије и реалке Кнежевине Србије (друго ирерађено и раширено издање), Београд: издање и штампа државне штампарије.

Новаковић ${ }^{4}$ 1880: Стојан Новаковић, Срйска грамайика за ниже гимназије и реалке у Кнежевини Србији, IV, Наука о реченицама (синйакса), Београд: Издање и штампа државне штампарије.

Новаковић 1888: Стојан Новаковић, Српска краљевска акдемија и неговање језика српског, посланица академији наука философских, прочитана на свечаном скупу академије, држаном 10. Септембра 1888 у славу стогодишњице Вука Стеф. Караџића, Глас Срйске краљевске академије, X, Београд: Краљевско-српска државна штампарија, 1-88.

Петковић 1935: Сава Петковић, Речник ирквенословенског језика, Сремски Карловци: Српска манастирска штампарија.

Пипер и др. 2005: Предраг Пипер, Ивана Антонић, Владислава Ружић, Срето Танасић, Људмила Поповић, Бранко Тошовић, Синйакса савременог срйског језика, Простиа речениия, Београд: Институт за српски језик САНУ, Београдска књига; Нови Сад: Матица српска.

Поповић 1997: Љубомир Поповић, Ред речи у реченищи, Београд: Друштво за српски језик и књижевност Србије.

PМC 1967-1976: Речник срйскохрвайског књижевног језика, I-VI, Нови Сад: Матица српска.

PCP 1998: Руско-срӣски речник (у редакиији Богољуба Сйанковића), Нови Сад: Матица српска, Москва: Русский язык.

Силић 1984: Josip Silić, Od rečenice do teksta (teoretsko-metodološke pretpostavke nadrečeničnog jedinstva), Zagreb: Liber. 
Симић 1991: Радоје Симић, О нашем књижевном језику, Никшић: НИП „Универзитетска ријеч”.

Симић/Јовановић 2002: Радоје Симић, Јелена Јовановић, Срйска синйакса, I-II, Београд: Научно друштво за неговање српског језика.

Симић/Јовановић 2002: Радоје Симић, Јелена Јовановић, Срйска синйакса, $I I I-I V$, Београд: Научно друштво за неговање српског језика.

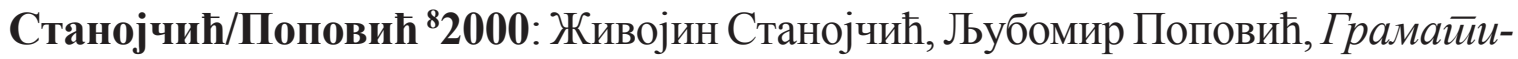
ка сриискога језика, Уибеник за I, II, III и IV разред средње школе, Београд: Завод за уџбенике и наставна средства.

Стевановић 1989: Михаило Стевановић, Савремени срйскохрвайски језик II, Синйакса, Београд: Народна књига.

Тошовић 2002: Бранко Тошовић, Функиионални сииилови, Београд: Београдска књига.

Халупка Решетар 2009: Sabina Halupka-Rešetar, Red reči u službi izražavanja informacionog fokusa u srpskom jeziku, Зборник Майице срйске за филологију и лингвистиику, LII/2, 169-186.

Шћепановић 2011: Михаило Шћепановић, Ред речи на размеђи основице и надградње српског језика, Срйски језик, XVI, 505-512.

\section{A THEORETICAL APPROACH TO WORD ORDER IN SERBIAN GRAMMARS AND LINGUISTIC STUDIES IN THE LATE 18TH AND THE FIRST HALF OF THE 19TH CENTURIES}

\section{Summary}

The paper presents, analyses and theoretically discusses word order as a specific syntactic representative of the age in 18th- and 19th-century grammars and linguistic studies.

It is our intention to ascertain whether the attitudes of grammarians of the age follow the syntactic features of the Slavonic Serbian period, and on the other hand, whether those features indicate the syntactic specificities of the vernacular (spoken) language of the age, which may provide an indirect pathway into the specificities of the contemporary Serbian language. 